\title{
Global isoprene emissions estimated using MEGAN, ECMWF analyses and a detailed canopy environment model
}

\author{
J.-F. Müller ${ }^{1}$, T. Stavrakou ${ }^{1}$, S. Wallens ${ }^{1}$, I. De Smedt ${ }^{1}$, M. Van Roozendael ${ }^{1}$, M. J. Potosnak ${ }^{2}$, J. Rinne ${ }^{3}$, B. Munger ${ }^{4}$, \\ A. Goldstein ${ }^{5}$, and A. B. Guenther ${ }^{6}$ \\ ${ }^{1}$ Belgian Institute for Space Aeronomy, Brussels, Belgium \\ ${ }^{2}$ Desert Research Institute, Reno, NV, USA \\ ${ }^{3}$ Department of Physics, University of Helsinki, Finland \\ ${ }^{4}$ Harvard University, Cambridge, MA, USA \\ ${ }^{5}$ University of California, Berkeley, CA, USA \\ ${ }^{6}$ National Center for Atmospheric Research, Boulder, CO, USA
}

Received: 14 September 2007 - Published in Atmos. Chem. Phys. Discuss.: 1 November 2007

Revised: 25 January 2008 - Accepted: 11 February 2008 - Published: 6 March 2008

\begin{abstract}
The global emissions of isoprene are calculated at $0.5^{\circ}$ resolution for each year between 1995 and 2006, based on the MEGAN (Model of Emissions of Gases and Aerosols from Nature) version 2 model (Guenther et al., 2006) and a detailed multi-layer canopy environment model for the calculation of leaf temperature and visible radiation fluxes. The calculation is driven by meteorological fields - air temperature, cloud cover, downward solar irradiance, windspeed, volumetric soil moisture in 4 soil layers - provided by analyses of the European Centre for Medium-Range Weather Forecasts (ECMWF). The estimated annual global isoprene emission ranges between $374 \mathrm{Tg}$ (in 1996) and $449 \mathrm{Tg}$ (in 1998 and 2005), for an average of ca. $410 \mathrm{Tg} /$ year over the whole period, i.e. about $30 \%$ less than the standard MEGAN estimate (Guenther et al., 2006). This difference is due, to a large extent, to the impact of the soil moisture stress factor, which is found here to decrease the global emissions by more than $20 \%$. In qualitative agreement with past studies, high annual emissions are found to be generally associated with El Niño events. The emission inventory is evaluated against flux measurement campaigns at Harvard forest (Massachussets) and Tapajós in Amazonia, showing that the model can capture quite well the short-term variability of emissions, but that it fails to reproduce the observed seasonal variation at the tropical rainforest site, with largely overestimated wet season fluxes. The comparison of the HCHO vertical columns calculated by a chemistry and transport model (CTM) with HCHO
\end{abstract}

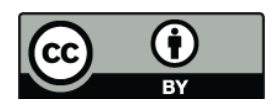

Correspondence to: J.-F. Muller (jfm@aeronomie.be) distributions retrieved from space provides useful insights on tropical isoprene emissions. For example, the relatively low emissions calculated over Western Amazonia (compared to the corresponding estimates in the inventory of Guenther et al., 1995) are validated by the excellent agreement found between the CTM and HCHO data over this region. The parameterized impact of the soil moisture stress on isoprene emissions is found to reduce the model/data bias over Australia, but it leads to underestimated emissions near the end of the dry season over subtropical Africa.

\section{Introduction}

The emissions of biogenic volatile organic compounds (BVOCs) have multiple impacts on the atmospheric composition, including enhanced ozone formation rates in polluted areas, decreased oxidizing capacity of the global troposphere, and substantial contribution to tropospheric aerosol abundances in continental regions (Seinfeld and Pandis, 1998). Among the BVOCs, isoprene is the most largely emitted compound, with global annual emissions on the order of $600 \mathrm{Tg}$ /year (Guenther et al., 2006). Whereas fixed emission inventories have been widely used by global atmospheric chemistry and transport models (CTMs) in the last decade (e.g. Dentener et al., 2006), the importance of meteorology as source of spatiotemporal variability in BVOC emissions has led to the implementation of interactive emission models in CTMs, which make use of the CTM meteorology for estimating the emissions (e.g. Pfister et al., 2008). It has also been shown that climate change can potentially induce large

Published by Copernicus Publications on behalf of the European Geosciences Union. 
long-term term changes in global emissions (Sanderson et al., 2003; Guenther et al., 2006) and that meteorological variability, and in particular El Niño events, induce a significant interannual variability of global emissions (Lathière et al., 2006).

Since the first global emission models (Müller, 1992; Guenther et al., 1995), which parameterized the emissions as functions of the instantaneous temperature and radiation levels, the influence of meteorology on the emissions has been seen from measurements to be more complex. Among other factors, the past environmental conditions (temperature, light) experienced by the leaves, the soil moisture stress, and the age of leaves have well-identified impacts on the emissions, even though their quantitative influence remains uncertain (see Guenther et al., 2006, and references therein). These effects are now parameterized in the MEGAN model (Model of Emissions of Gases and Aerosols from Nature) version 2 (Guenther et al., 2006). This model incorporates the results of numerous field and laboratory investigations, and includes a high resolution database for the distribution of plant functional types (PFTs) and of their basal emission factor (i.e. their emission rates in standard conditions), as described in Sect. 2.1. Although the leaf-level radiation fluxes and temperatures are the most important parameters driving the emissions, their parameterizations are generally crude and/or poorly described in past studies of isoprene emissions and their impact on the atmosphere (Guenther et al., 1995; Sanderson et al., 2003; Lathière et al., 2006; Palmer et al., 2006; Pfister et al., 2008). The effects of such shortcomings on the estimated sensitivity of emissions to meteorological variability and climate change are not well quantified.

A first purpose of this article is to provide a complete description of a multi-layer canopy environment model, MOHYCAN (MOdel for Hydrocarbon emissions by the CANopy), including the treatment used for radiative transfer in the canopy and the calculation of leaf temperature (see Sect. 2.2 and the supplement to this article at http://www.atmos-chem-phys.net/8/1329/ 2008/acp-8-1329-2008-supplement.pdf). Secondly, this model is coupled with MEGAN to calculate the global emissions of isoprene at $0.5^{\circ} \times 0.5^{\circ}$ resolution, and to investigate their interannual variability between 1995 and 2006, based on meteorological fields provided by ECMWF analyses (Sect. 3). The inventory is available in NetCDF format at http://www.oma.be/TROPO/inventory.html. Thirdly, this inventory is evaluated against two types of measurements: local isoprene flux measurements at selected sites (Sect. 4), and spaceborne measurements of the integrated vertical columns of formaldehyde (HCHO), a known by-product of isoprene degradation in the atmosphere (Sect. 5).

\section{Model description}

\subsection{MEGAN}

The isoprene emission algorithm is based on the MEGAN model (Guenther et al., 2006). The emission rate of a volatile organic compound is expressed in MEGAN as

$F=\varepsilon \cdot \gamma \cdot \rho$,

where $\varepsilon$ is the standard emission factor $\left(\mathrm{mg} \mathrm{m}^{-2} \mathrm{~h}^{-1}\right)$, i.e. the emission rate at standardized conditions defined in Guenther et al. (2006), and $\gamma$, the activity factor, represents the response to deviations from these standard conditions. $\rho$, which represents the influence of production and losses within the canopy, is taken equal to one in this study. We use the MEGAN EFv2.0 dataset (also used in Guenther et al., 2006), which provides the geographical distribution of both the fractional cover and the standard emission factor of six plant functional types (PFTs): needleleaf evergreen trees, needleleaf deciduous trees, broadleaf trees, shrubs, grass and crops. Here a further distinction between evergreen and deciduous broadleaf trees is made (since these plant types have different canopy features), based on the global ecosystem database of Olson et al. (1985). The emission flux at any location is therefore a sum of contributions from all PFTs present at this location. The activity factor $\gamma$ is given by

$\gamma=C_{C E} \cdot \gamma_{P T} \cdot \mathrm{LAI} \cdot \gamma_{\mathrm{age}} \cdot \gamma_{S M}$,

where $C_{C E}=0.52$ is an adjustment factor so that $\gamma=1$ at standard conditions, $\gamma_{P T}$ is the weighted average (for all leaves) of the product of the activity factors for leaf temperature and PPFD (photosynthetic photon flux density), LAI is the leaf area density $\left(\mathrm{m}^{-2} \mathrm{~m}^{-2}\right), \gamma_{\text {age }}$ and $\gamma_{S M}$ are the leaf age and soil moisture activity factors, respectively. Since leaf temperature and PPFD vary with height due to light attenuation by leaves, the canopy is divided into $n$ layers in the canopy environment model which further distinguishes between sunlit and shade leaves, so that

$$
\begin{aligned}
\gamma_{P T} \cdot \mathrm{LAI}= & \sum_{j}\left[\left(\left(\gamma_{P}^{j}\right)_{\text {sun }} \cdot\left(\gamma_{T}^{j}\right)_{\text {sun }} \cdot f_{\text {sun }}^{j}+\right.\right. \\
& \left.\left.\left(\gamma_{P}^{j}\right)_{\text {shade }} \cdot\left(\gamma_{T}^{j}\right)_{\text {shade }} \cdot f_{\text {shade }}^{j}\right) \cdot \Delta \mathrm{LAI}_{j}\right],
\end{aligned}
$$

where the index $j$ runs over all layers, $\Delta \mathrm{LAI}_{j}$ is the partial LAI in layer $j, \gamma_{P}^{j}$ and $\gamma_{T}^{j}$ are the PPFD and leaf temperature activity factors at layer $k$ (for either shade or sunlit leaves), and $f_{\text {sun }}^{j}$ and $f_{\text {shade }}^{j}=1-f_{\text {sun }}^{j}$ are the fractional sunlit and shaded area in this layer. The number of layers is set to eight in this study in order to minimize the numerical error associated with vertical discretization. The leaf area index is evenly distributed between the $n$ layers, i.e. $\Delta \mathrm{LAI}_{j}=\mathrm{LAI} / n$. Note that $\gamma_{P T}$ has to be calculated separately for each PFT, because of differences in their canopy characteristics (see Table 1 in the supplement to 
this article: http://www.atmos-chem-phys.net/8/1329/2008/ acp-8-1329-2008-supplement.pdf).

The light dependence is given by

$\gamma_{P}=\frac{C_{P} \cdot \alpha \cdot \mathrm{PPFD}}{\sqrt{1+\alpha^{2} \cdot \mathrm{PPFD}^{2}}}$,

where PPFD is calculated at leaf level $\left(\mu \mathrm{mol} \mathrm{m}{ }^{-2} \mathrm{~s}^{-1}\right) . \alpha$ and $C_{P}$ depend on the past history of light intensity according to

$\alpha=0.004-0.0005 \cdot \ln \left(P_{240}\right)$

$C_{P}=0.0468 \cdot \exp \left(0.0005 \cdot\left[P_{24}-P_{0}\right]\right) \cdot\left(P_{240}\right)^{0.6}$,

where $P_{24}$ and $P_{240}$ are the PPFD averages over the past 24 and $240 \mathrm{~h}$, respectively, and $P_{0}$ is equal to $200 \mu \mathrm{mol} \mathrm{m}^{-2} \mathrm{~s}^{-1}$ for sunlit leaves and $50 \mu \mathrm{mol} \mathrm{m}^{-2} \mathrm{~s}^{-1}$ for shaded leaves. The temperature dependence is expressed as

$\gamma_{T}=\frac{E_{\mathrm{opt}} \cdot C_{T 2} \cdot \exp \left(C_{T 1} \cdot \frac{\left(T_{l}-T_{\mathrm{opt}}\right)}{R T_{l} T_{\mathrm{opt}}}\right)}{C_{T 2}-\left(C_{T 1} \cdot\left[1-\exp \left(C_{T 2} \cdot \frac{\left(T_{l}-T_{\mathrm{opt}}\right)}{R T_{l} T_{\mathrm{opt}}}\right)\right]\right)}$,

where $C_{T 1}=95000 \mathrm{~J} \mathrm{~mol}^{-1}$ and $C_{T 2}=230000 \mathrm{~J} \mathrm{~mol}^{-1}, T_{l}$ $(\mathrm{K})$ is leaf temperature, $R\left(=8.31 \mathrm{~J} \mathrm{~K}^{-1} \mathrm{~mol}^{-1}\right)$ is the universal gas constant, $E_{\text {opt }}$ is the maximum normalized emission capacity, and $T_{\mathrm{opt}}$ is the temperature at which $E_{\mathrm{opt}}$ occurs. These coefficients are estimated as a function of the average leaf temperature over the past $24 \mathrm{~h}\left(T_{24}\right)$ and $240 \mathrm{~h}\left(T_{240}\right)$ :

$$
\begin{aligned}
E_{\mathrm{opt}}=2.034 & \cdot \exp \left(0.05 \cdot\left[T_{24}-297\right]\right) \\
& \cdot \exp \left(0.05 \cdot\left[T_{240}-297\right]\right)
\end{aligned}
$$

with

$T_{\text {opt }}=313+0.6 \cdot\left(T_{240}-297\right)$.

The leaf age activity factor $\gamma_{\text {age }}$ is estimated for deciduous canopies as

$\gamma_{\text {age }}=F_{\text {new }} \cdot A_{\text {new }}+F_{\text {gro }} \cdot A_{\text {gro }}+F_{\text {mat }} \cdot A_{\text {mat }}+F_{\text {old }} \cdot A_{\text {old }}$,

where $A_{\text {new }}=0.05, A_{\text {gro }}=0.6, A_{\text {mat }}=1.125, A_{\text {old }}=1$, and $F_{\text {new }}, F_{\text {gro }}, F_{\text {mat }}$ and $F_{\text {old }}$ are the fractions of new, growing, mature and old leaves, respectively. These fractions are parameterized from LAI changes between the current and previous time steps and from the average temperature over the past 15 days, as described in Guenther et al. (2006).

Finally, the emission response to soil moisture stress, $\gamma_{S M}$, is estimated as

$\gamma_{S M}=\sum_{l}\left[f_{\text {root }}^{l} \cdot \max \left(0, \min \left(1,\left(\theta^{l}-\theta_{w}\right) / 0.06\right)\right)\right]$,

where $f_{\text {root }}^{l}$ is the fraction of roots within the soil layer $l, \theta^{l}$ is the volumetric soil water content in this layer $\left(\mathrm{m}^{3} \mathrm{~m}^{-3}\right)$, and $\theta_{w}$ is the wilting point. The distribution of roots is estimated following Zeng (2001). Although this distribution is PFTdependent, the use of a unique profile $(26 \%, 39 \%, 29 \%$ and $6 \%$ at the 4 layers of the ECMWF numerical weather prediction model: $0.07 \mathrm{~m}, 0.21 \mathrm{~m}, 0.72 \mathrm{~m}$ and $1.89 \mathrm{~m}$, respectively) is found to cause negligible errors on the estimation of $\gamma_{S M}$ in most situations.

\subsection{The canopy environment model}

A canopy environmental model (MOHYCAN, for MOdel for Hydrocarbon emissions by the CANopy) (Wallens, 2004) is used to determine leaf temperature and the radiation fluxes as functions of height inside the canopy. Radiative transfer is based on the framework of Goudriaan and van Laar (1994) (see also Leuning et al., 1995). Solar radiation is attenuated by foliage according to an exponential law, as described in more detail in the supplement. Distinct values of the extinction coefficient $\kappa$ are used for direct and for diffuse light, as well as for visible and NIR (Near Infrared Radiation). The leaves are characterized by diffusion and transmission coefficients.

The direct and diffuse fractions of solar radiation depend on solar zenith angle and cloud optical depth. The latter is estimated from the PPFD at canopy top, based on tabulated irradiances calculated by an atmospheric radiative transfer model (Madronich and Flocke, 1998). Leaf temperature in each canopy layer is determined from the energy balance equation (Goudriaan and van Laar, 1994; Leuning et al., 1995)

$$
Q_{S W}+Q_{L W}-Q_{S H}-Q_{L H}=Q_{\text {storage }} \quad\left[\mathrm{W} \mathrm{m}^{-2}\right],
$$

where $Q_{S W}$ is the absorbed solar (shortwave) irradiation, $Q_{L W}$ is the net longwave radiation emitted/absorbed by the leaf, $Q_{S H}$ is the sensible heat flux, $Q_{L H}$ is the latent heat flux of evaporation, and $Q_{\text {storage }}$ is the energy storage change. $Q_{\text {storage }}$ is much smaller than the other terms, and can be neglected. The determination of the leaf energy budget terms $Q_{L W}, Q_{S H}$ and $Q_{L H}$ involves parameterizations of the resistances for the exchange of heat and water vapor, and is described in the Supplement.

In summary, the input variables of the model are values at canopy top of solar radiation (PPFD+NIR), including their diffuse and direct components, air temperature, relative humidity and windspeed. Air temperature and water vapor pressure are assumed to be constant in the canopy. Attenuation of windspeed by foliage is parameterized, as described in the Supplement. Based on these assumptions, the model calculates PPFD and NIR for sunlit and shaded leaves at each level. Leaf temperature is determined iteratively using Eq. (12). The number of required iterations is in general less than 4. 


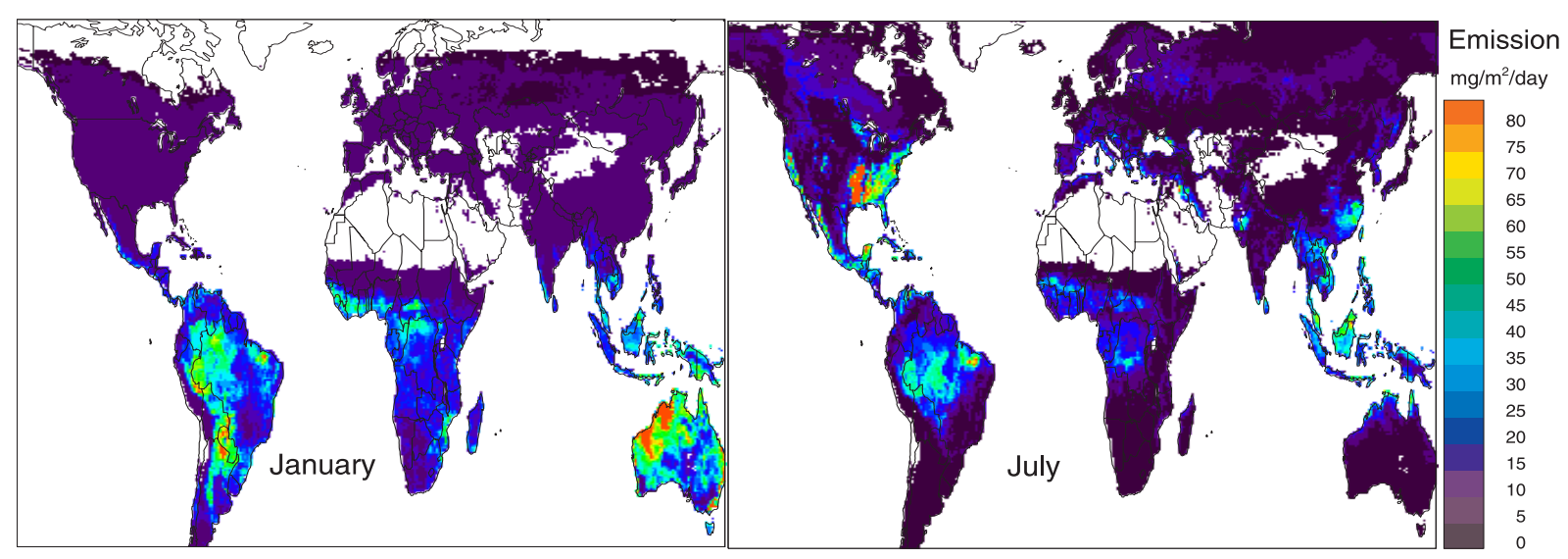

Fig. 1. Monthly averaged isoprene emissions $\left(\mathrm{mg} \mathrm{m}^{-2} \mathrm{day}^{-1}\right)$ in January (left) and in July (right) 2003, calculated in this study.

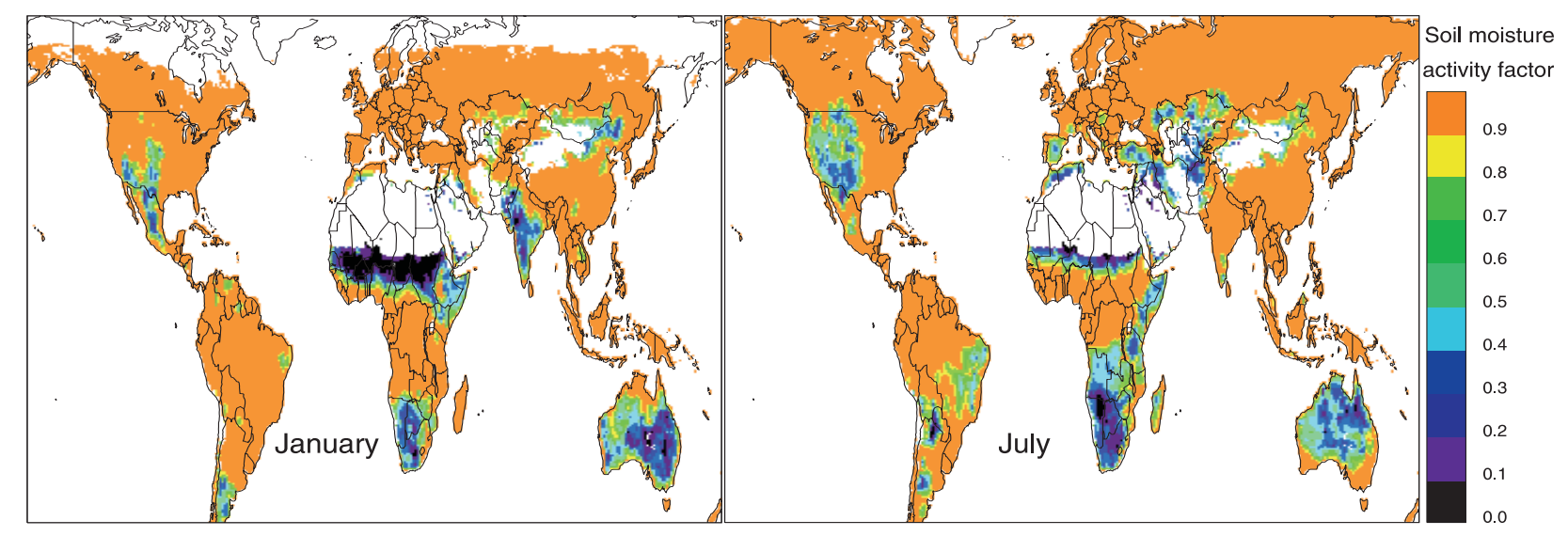

Fig. 2. Soil moisture activity factor $\left(\gamma_{S M}\right)$ in January (left) and in July (right) 2003, calculated in this study.

\subsection{Meteorology and LAI dataset}

We drive the canopy environment model with ECMWF fields for the downward solar radiation flux, the cloud cover fraction, the soil moisture content in 4 soil layers, and the air temperature, dewpoint temperature, and windspeed directly above the canopy. Reanalysed ERA40 fields are used untill 2001, whereas operational analyses are used beyond this date. The data are provided every $6 \mathrm{~h}$ on a N80 spectral grid (approximately 1.125 degree in longitude and latitude), and are re-gridded at $0.5 \times 0.5$ degree. A sinusoidal fit is applied to air and dewpoint temperature in order to derive hourly values of air temperature and relative humidity. The atmospheric radiative transfer model is used to determine the cloud optical depth from the cloud cover fraction and the solar radiation flux. Hourly values for the diffuse and direct solar radiation fluxes in both clear and cloudy conditions are derived from the assumption of constant cloud cover and cloud optical depth in each 6-h interval. The ratio of PPFD to total solar radiation is taken from the ISCCP D2 dataset (Rossow et al., 1996, http://isccp.giss.nasa.gov/). NIR is as- sumed to account for the remainder of solar radiation, i.e. UV is neglected (Goudriaan and van Laar, 1994). Since we use ECMWF soil moisture data, the ECMWF model values for the wilting point $\left(0.171 \mathrm{~m}^{3} \mathrm{~m}^{-3}\right)$ and the soil moisture at capacity $\left(0.323 \mathrm{~m}^{3} \mathrm{~m}^{-3}\right)$ are used in the parameterizations for the soil moisture dependence of the emissions and the stomatal resistance.

Monthly LAI values at $0.5 \times 0.5$ degree resolution from the MODIS dataset (February 2000-December 2006) are used (Zhang et al., 2004). Monthly climatological LAI values derived from the same dataset are used before this period. As in Guenther et al. (2006), the LAI of vegetated areas is estimated by dividing the MODIS LAI by the vegetated fraction of the grid.

\section{Global isoprene emission inventory 1995-2006}

\subsection{Inventory for year 2003}

The monthly averaged isoprene fluxes for January and July 2003 are illustrated on Fig. 1. The global annual isoprene 


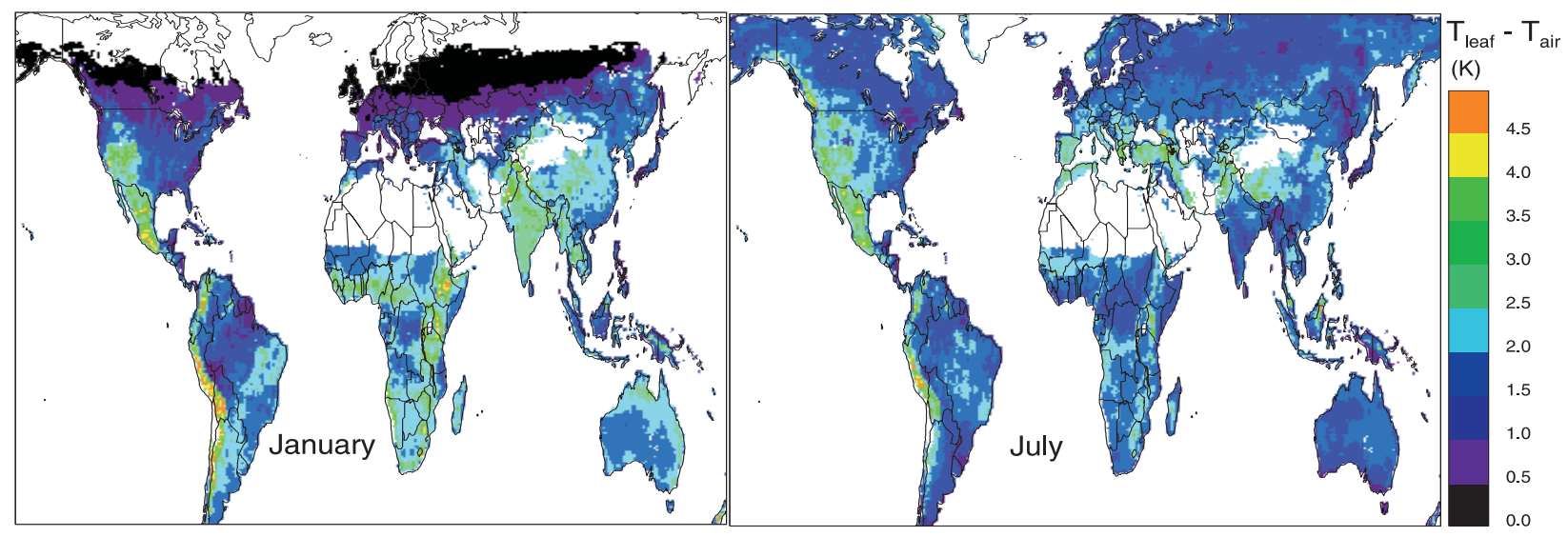

Fig. 3. Calculated difference between leaf temperature (weighted average) and air temperature, for the months of January (left panel) and July (right) in 2003.

source is estimated to $412 \mathrm{Tg} / \mathrm{year}$ in 2003 , or about $30 \%$ less than in the estimations by Guenther et al. (1995) (the GEIA 1995 evaluation) and Guenther et al. (2006). The latter evaluation was based on the MEGAN algorithm and NCEP meteorological data. The datasets used for Leaf Area Index, the distributions of the plant functional types and their associated basal emission factors were identical in this study and in Guenther et al. (2006). Besides the use of NCEP, other differences with the present work included the radiative transfer model, the calculation of leaf temperature, and the wilting point database.

Comparison of our Fig. 1 with the corresponding distributions of Fig. 10 in Guenther et al. (2006) shows a excellent agreement regarding the spatial patterns of the emissions in most regions, with the noticeable exception of Australia and other arid areas. The annual emissions over Northern America calculated in this work are also in excellent agreement with the estimation by Palmer et al. (2006) based on MEGAN and NCEP data, i.e. they are about $10 \%$ lower than in the GEIA evaluation (boundaries are as in Fig. 2 in Palmer et al., 2006) when the soil moisture stress effect is neglected, in accordance with Palmer et al. (2006). The largest source of difference between Guenther et al. (2006) or Palmer et al. (2006) and the present evaluation lies precisely in the soil moisture activity factor, $\gamma_{S M}$. The use of ECMWF soil moisture data together with the wilting point of the ECMWF model $\left(=0.171 \mathrm{~m}^{3} \mathrm{~m}^{-3}\right)$ leads to an important reduction of the emissions, illustrated on Fig. 2. On the global scale, the reduction reaches $21 \%$, i.e. the global emission would amount to $518 \mathrm{Tg} / \mathrm{yr}$ if this factor were taken equal to 1 . An even larger reduction would be obtained by using the NCEP/NCAR reanalysis fields for soil moisture (data obtained from www.cdc.noaa.gov/cdc/data.ncep.reanalysis. html) (Kalnay et al., 1996), together with the wilting point used in this reanalysis $\left(=0.1 \mathrm{~m}^{3} \mathrm{~m}^{-3}\right)$. In contrast with these results, the use of the wilting point database of Chen and
Dudhia (2001) in Guenther et al. (2006) led to a comparatively smaller impact of this activity factor on the emissions (7\% globally). Although the high-resolution database of Chen and Dudhia (2001) is probably more realistic than the fixed values used by ECMWF and NCEP/NCAR, it is not appropriate for use in calculations using the soil moisture fields from these analyses, given the importance of the wilting point in the determination of soil moisture in climate models (Maurer et al., 2002; Li and Robock, 2005). As seen on Fig. 2, the emission reduction calculated in this work is largest in subtropical Africa and Australia during the dry season and reaches one order of magnitude in desert areas. Annual North American isoprene emissions are reduced by ca. $10 \%$, mostly due to decreases in the Western U.S. The calculated impact of soil moisture stress should be considered with caution, since its parameterization is unfortunately based on measurements from only one study (Pegoraro et al., 2004), and because soil moisture is not directly constrained by measurements in meteorological analyses.

Other causes might contribute to the lower global emissions estimated in this work, compared to previous estimations. Wallens (2004) estimated that the treatment of light attenuation in the canopy used in the MOHYCAN model leads to lower emissions (10\% globally) than the parameterization used in Guenther et al. (1995). As discussed by Guenther et al. (2006), the LAI values from the MODIS dataset are considerably lower than in previous estimations and contribute to lower the global emissions by $>20 \%$. The diurnal cycle of temperature, not accounted for in Guenther et al. (1995), contributes to enhance the emissions, but this is compensated by the lower PPFD values from the meteorological analyses, compared with the PPFD fluxes used in Guenther et al. (1995). The use of leaf temperature instead of air temperature in the emission algorithm contributes to increase the global (or the North American) annual emission estimate by $18 \%$ according to our calculations. The difference between 


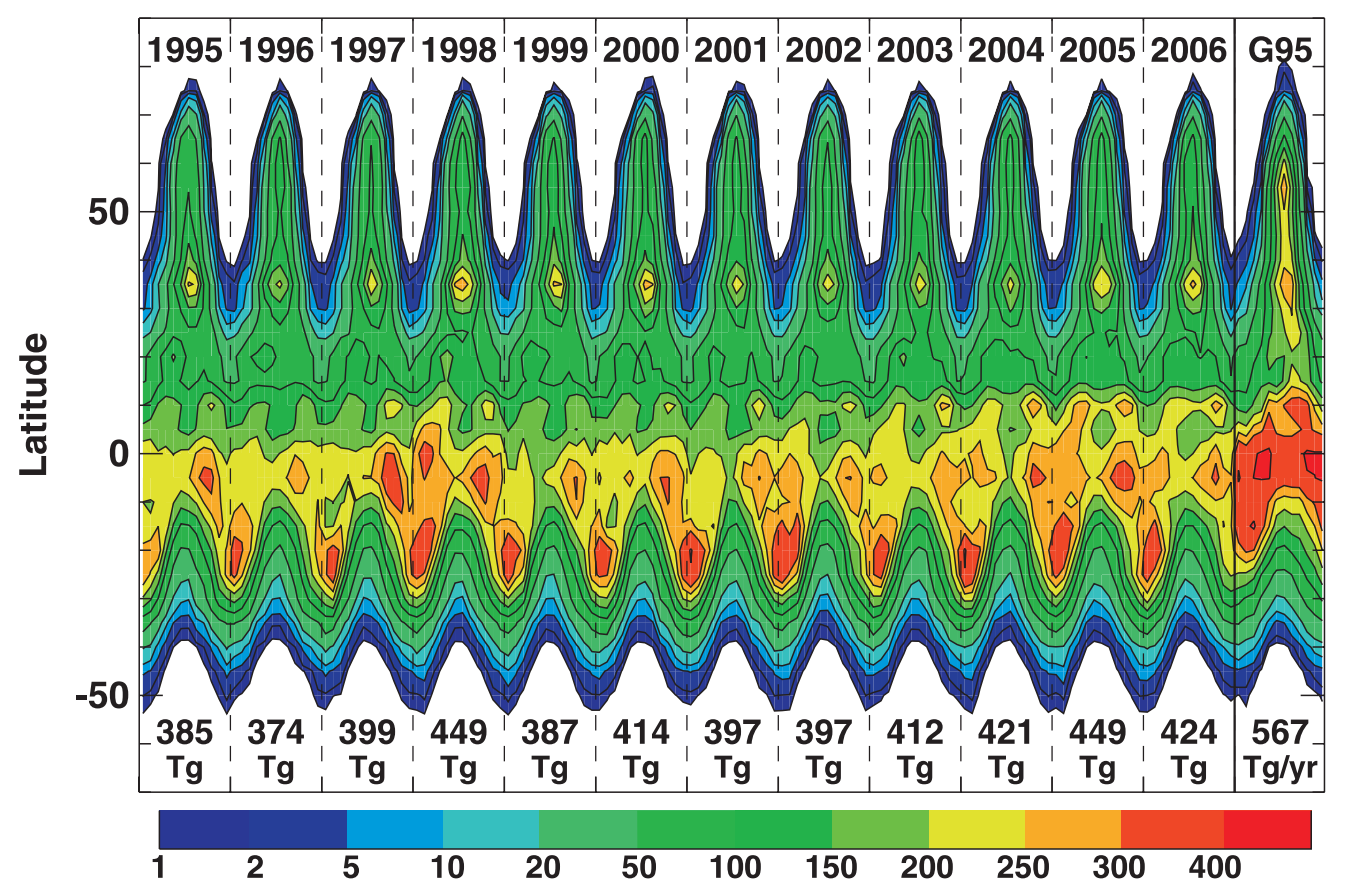

Fig. 4. Zonally and monthly averaged isoprene emissions $\left(\mu \mathrm{g} \mathrm{m}^{-2} \mathrm{~h}^{-1}\right)$ between 1995 and 2006, as calculated in this study, and compared with the zonally averaged emissions of the G95 inventory (Guenther et al., 1995). The global yearly emission is also given for each year and for the G95 inventory.

leaf temperature (average weighted by the emissions) and air temperature is illustrated in Fig. 3. Leaves are found to be about 1-2 K warmer than their environment over most forest areas, resulting in emission enhancements of ca. $10 \%$. Over savannas and desert areas, generally characterized by little cloud cover and high PPFD fluxes, the difference often exceeds $2 \mathrm{~K}$, and leads to emission increases which can exceed $30 \%$.

\subsection{Interannual variability, 1995-2006}

Figure 4 shows the evolution of the zonally averaged isoprene emissions between 1995 and 2006, and a comparison with the corresponding values for the emissions of the Guenther et al. (1995) (G95) inventory. The largest differences are seen near the Equator and around $55^{\circ} \mathrm{N}$, with zonally averaged emissions about a factor of 2 lower in the present study, compared to GEIA. The annual global totals are also given on the figure. The annual emissions range between $374 \mathrm{Tg} /$ year (in 1996) and $449 \mathrm{Tg} /$ year (in 1998 and 2005). The maximum interannual variability in the 19952006 period amounts to $20 \%$, i.e. about twice more than in the study of Lathière et al. (2006) covering the period 19831995. As already noted by Naik et al. (2004) and Lathière et al. (2006), high emissions are often associated to El Niño years (e.g. 1997/1998), and low emissions to La Niña years (e.g. 1995/1996). There are exceptions to this rule, though, since 1994/1995 was an El Niño year, and 2004/2005 was only a weak El Niño. Lathière et al. (2006) showed that the monthly Southern Oscillation Index (SOI, i.e. the pressure difference between Tahiti and Darwin) shows a negative correlation with the calculated isoprene emissions over South America, Indonesia and other tropical locations. Correlations were found to be negligible at temperate and boreal latitudes. We compare in Fig. 5 the monthly Oceanic Niño Index $(\mathrm{ONI})$ with the annual tropical isoprene emissions $\left(23^{\circ} \mathrm{S}-\right.$ $23^{\circ} \mathrm{N}$ ) between 1995 and 2006. Large positive ONI values correspond to El Niño events. The tropical emissions appear to be positively correlated with the ONI time-shifted by about 6 months. A qualitatively similar result can be obtained with the global annual isoprene emissions. The observed correlation probably explains the apparent positive trend in the global emissions between 1999 and 2005 (Fig. 5), a period of gradual increase of the ONI. The 6-month delay reflects the complex influence of El Niño (or La Niña) on different regions of the world, as illustrated by the geographical distribution of the correlation coefficient between ONI and the monthly emission anomalies (Fig. 6). Note that essentially identical results, but of opposite sign, are obtained for the correlation of the emissions with the SOI index. The emissions are positively correlated with ONI over many regions in South America, Africa, Siberia and Alaska, but they are negatively correlated with ONI over the U.S., Australia and many other regions. As a result, global isoprene emissions are not strongly correlated with the ONI (or SOI) index. The correlation coefficient between ONI (SOI) and the monthly 
global emissions is $0.12(-0.07)$, i.e. much less than in the studies of Lathière et al. (2006) and Naik et al. (2004). However, isoprene emissions are found to be positively correlated with the ONI delayed by 6 months in almost all regions, as seen on the right panel of Fig. 6. The correlation coefficient between the lagged ONI (SOI) and the monthly global emissions reaches $0.38(-0.32)$. Note that essentially similar results are obtained when the climatological LAI dataset is used for calculating the emissions during the whole period (1995-2006), i.e., the interannual variability of LAI is found to have a only a small impact on the variability of isoprene emissions.

\section{Comparison with campaign measurements}

The inventory is tested against campaign measurements at mid-latitudes (Harvard forest) and in Amazonia (Tapajós). In both cases, model results are shown for the year in which observations were conduced.

\subsection{Harvard Forest, 1995}

Isoprene fluxes have been measured at Harvard Forest in Massachusetts $\left(42^{\circ} 32^{\prime} \mathrm{N}, 72^{\circ} 11^{\prime} \mathrm{W}\right)$ between June and October 1995 (Goldstein et al., 1998). The fluxes have been determined using the similarity gradient technique by multiplying the flux of $\mathrm{CO}_{2}$ (eddy covariance method) with the vertical gradient of isoprene concentration, then dividing by the vertical gradient of $\mathrm{CO}_{2}$ concentration. Measurements were performed on a $30 \mathrm{~m}$ tower extending $7 \mathrm{~m}$ above the canopy. The uncertainty of the measurements is about $30 \%$ (Goldstein et al., 1998).

The forest is composed of red oak (a strong isoprene emitter) and other species. Needleleaf evergreen and broadleaf deciduous trees represent $35 \%$ and $64 \%$ of the site area, respectively (Goldstein et al., 1998), in good agreement with the PFT distribution used in MEGAN (63\% and 67\% of broadleaf trees at the two nearest gridcells).

Our model calculations are compared with the measurements in Figs. 7 and 8. Although the observed diurnal cycle is relatively well reproduced by the model, an underestimation is noted (35\% on average), which probably reflects an underestimation of the standard emission factors in the model. The underestimation is highest around noon (40\%), and lowest at high solar zenith angles.

When corrected for the $35 \%$ bias, the model results reproduce remarkably well the seasonal as well as the dayto-day variations of isoprene fluxes between June and midSeptember (Fig. 8), with a correlation coefficient of about 0.90 . Before day 160 and after day 260 , however, the model largely overestimates the fluxes. The leaf age factor $\gamma_{\text {age }}$ calculated according to Eq. (10) lowers the emissions in spring and fall (as compared to summertime), but this reduction appears to be much too weak, or the response of the emissions

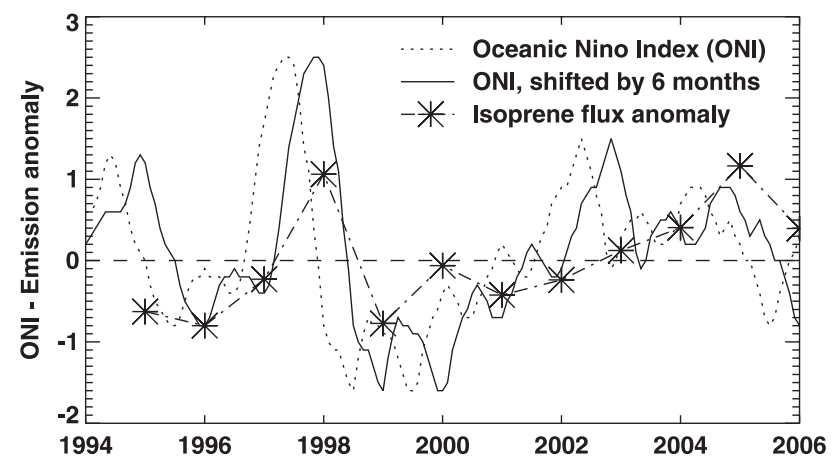

Fig. 5. Evolution of the Oceanic Niño Index (3-month running mean of Sea Surface Temperature anomalies in the region $5^{\circ} \mathrm{N}-$ $5^{\circ} \mathrm{S}, 120^{\circ}-170^{\circ} \mathrm{W}$ ) between 1994 and 2005 (dotted and solid lines), and annual tropical isoprene emission anomaly between 1995 and 2006 (symbols).

to LAI variations and the past weather conditions might be possibly underestimated.

\subsection{Tapajós}

Isoprene fluxes from a primary tropical rainforest in Brazil were measured during three separate field campaigns: April 2001 during the wet season, July 2000 at the end of the wet season, and October-November 2003 during the dry season. The technique used to collect these datasets was the eddy covariance-fast isoprene system (EC-FIS) technique (Guenther and Hills, 1998). All the measurements were conducted at the Floresta Nacional do Tapajós site $\left(2^{\circ} 51^{\prime} \mathrm{S}, 54^{\circ} 58^{\prime} \mathrm{W}\right)$ in the state of Pará run by S. Wofsy's group from Harvard University. This long-term $\mathrm{CO}_{2}$ flux tower was sponsored by the Large-scale Biosphere-atmosphere experiment in Amazonia (LBA). The July 2000 dataset has been previously reported (Rinne et al., 2002). The uncertainty of the measured fluxes is estimated to be about $30 \%$.

The April 2001 dataset was collected with the instrument mounted in-situ on a $60 \mathrm{~m}$ walk-up tower. A dedicated sonic anenometer collected wind data simultaneously.

The 2001 wet season and 2003 dry season measurements were also collected at the Tapajós site, but were performed on the $70 \mathrm{~m}$ tower in conjunction with the existing $\mathrm{CO}_{2}$ flux measurements. Air for the ground-based FIS system was drawn through $70-75 \mathrm{~m}$ of $6.4 \mathrm{~mm}$ OD teflon tubing $\left(111 \mathrm{~min}^{-1}\right.$ in 2003). The tubing inlet was within $1 \mathrm{~m}$ of the existing sonic anemometer installed at a height of $65 \mathrm{~m}$ during 2003. In 2001, a dedicated sonic anemometer was mounted at $70 \mathrm{~m}$ during the experiment. The FIS instrument was located in a building near the base of the tower and drew off $2.8-3.21 \mathrm{~min}^{-1}$ of air from the main flow. The FIS was manually zeroed each day by passing inlet air through a heated plantium catalyst. Due to importation difficulties, no isoprene standard was available on-site in 2003, but the FIS was calibrated both before departure and upon return 


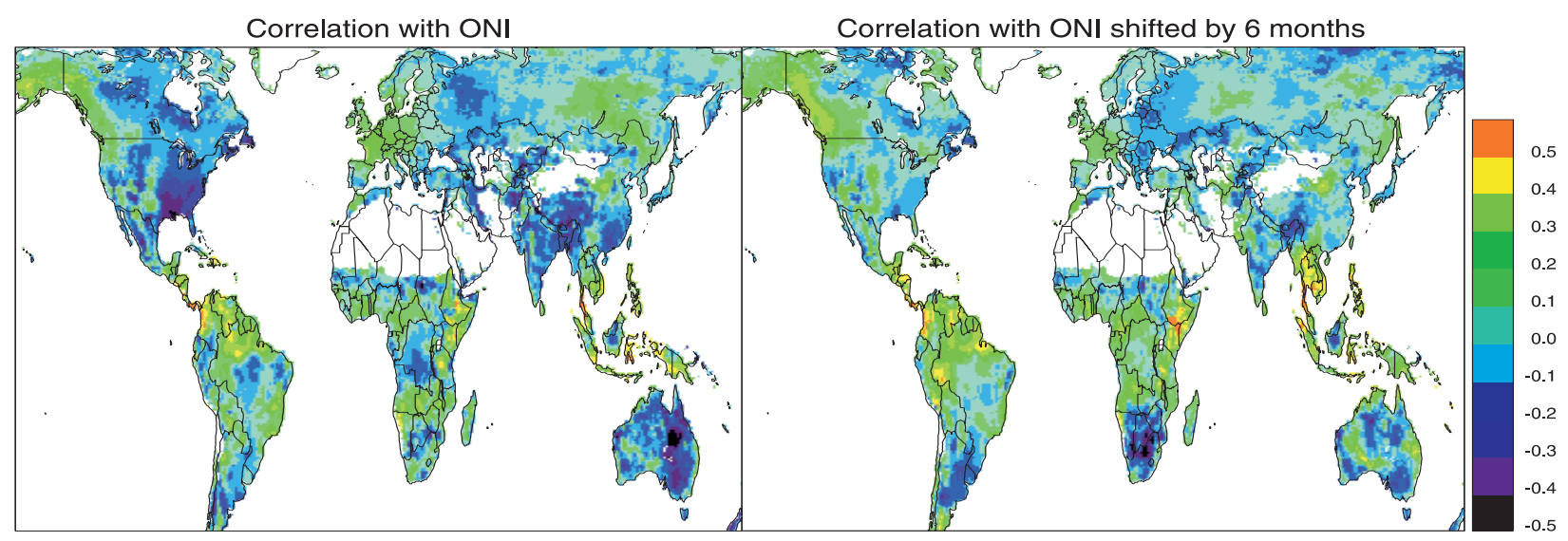

Fig. 6. Calculated coefficient for correlation between the monthly isoprene emission anomalies and the Oceanic Niño Index (ONI) between 1995 and 2006.

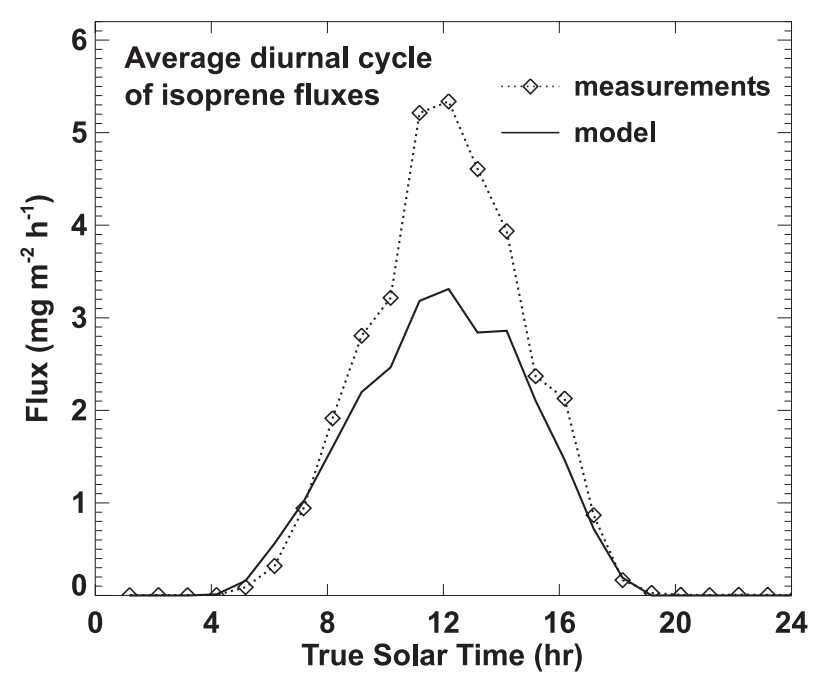

Fig. 7. Average diurnal variation of measured (diamonds) and modelled (solid line) isoprene fluxes (June-October) at Harvard Forest. The measurements are averaged over one-hour intervals. The model values have been calculated at the measurement times and averaged over the same intervals.

to the laboratory in the United States. Calibrations were performed by dilluting a high-concentration gas standard in 2001. Standard eddy covariance methodology was used to compute half-hour fluxes, but no corrections (e.g. the Webb correction) were applied to the data except for a 2-D wind rotation to ensure a zero vertical velocity. The teflon tube introduced a 5-6s delay between the datasets which was determined by examing the lag correlation for the half-hour periods.

The daily averaged emission fluxes are shown on Fig. 9. The model results agree well with the dry season measurements (red diamonds) when the standard emission factor is reduced by a factor 1.7. The model succeds in reproducing

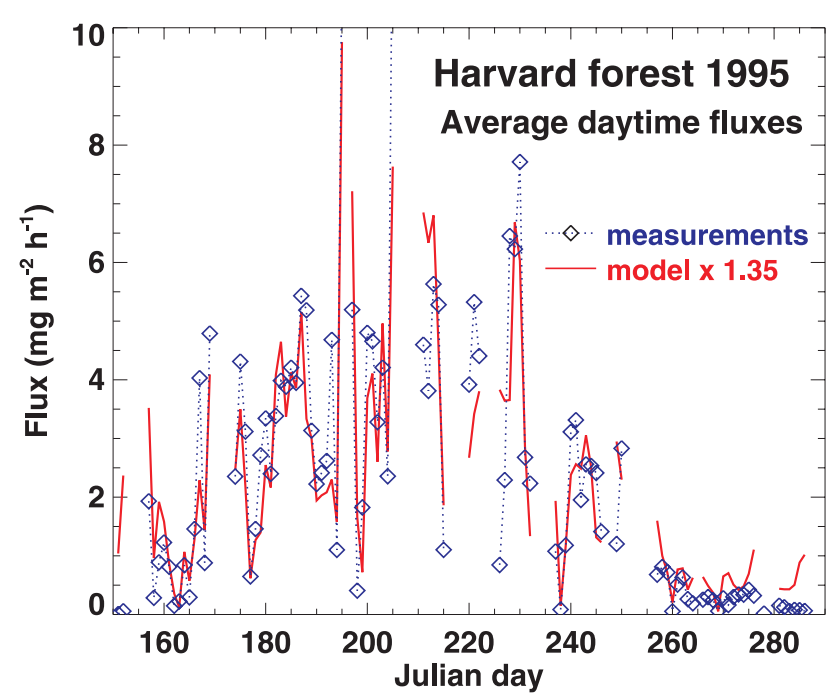

Fig. 8. Seasonal evolution of measured (diamonds) and modelled (solid line) isoprene fluxes (averages over daytime hours) at Harvard forest.

the steep decrease (factor of 3 ) in the emission rates in the course of the measurement period, between day 300 and day 308. This decrease is due to rapid changes in meteorological conditions during that period. The modelled emissions during the wet season (February-July) are almost a factor of 2 lower than during the dry season, due to lower LAI (Huete et al., 2006), lower PPFD fluxes and lower temperatures during that time period. Although this seasonality is much more pronounced than in the inventory of Guenther et al. (1995) (with only 15\% difference between April and September emissions at that site), the flux measurements at Tapajós indicate a even much stronger seasonality of isoprene fluxes. This result reinforces conclusions already drawn by e.g. Kuhn et al. (2004), based on isoprene emission capacity measurements at another Amazonian site, and 
Trostdorf et al. (2004), based on ambient isoprene measurements at Tapajós in 2001. For example, the measured fluxes in April 2001 are almost an order of magnitude lower than the dry season fluxes. In other terms, the standard emission factor should be a factor of 2-5 lower during the wet season, compared to the dry season. This probably cannot be explained by soil moisture effects, since the soil moisture stress factor $\left(\gamma_{S M}\right)$ is found to be always equal to one at this location, although it cannot be excluded that this parameterization is inappropriate for tropical rain forests. Trostdorf et al. (2004) have proposed to introduce a precipitation-based activity factor for isoprene emissions in order to better match the observations:

$E_{P}=2-1.5 \cdot \frac{P_{3}}{P_{3, \max }}$,

where $P_{3}$ is the average precipitation rate during the past 3 months, $P_{3, \max }$ is the maximum value of this average. Using precipitation rates from the ECMWF/ERA40 dataset, this factor is found to reduce wet season fluxes by a factor of 1.5, compared to the dry season fluxes, and is therefore not sufficient to reconcile the model with observations. Alternative models relating the emissions not only to environmental parameters, but also to physiological parameters like stomatal conductance, assimilation and intercellular $\mathrm{CO}_{2}$ concentration are more likely to help improving the prediction of isoprene emissions in tropical rainforests (Simon et al., 2005).

\section{Evaluation against formaldehyde data from satellite}

Isoprene being a major precursor of formaldehyde in the atmosphere, the vertical column distributions of this compound obtained from satellite instruments provide the opportunity to test and possibly improve the emission inventories. The GEOS-CHEM tropospheric chemical/transport model (CTM) has been used in several studies by the Harvard group to provide improved estimates of isoprene emissions based on HCHO columns retrieved from the GOME (Global Ozone Monitoring Experiment) instrument, in particular over the United States (Palmer et al., 2003; Abbott et al., 2003; Palmer et al., 2006), over China and Southeast Asia (Fu et al., 2007), and on the global scale (Shim et al., 2005). In regions where isoprene is the dominant precursor of formaldehyde, like the Eastern U.S. during summertime, the estimated uncertainty on these emissions is $\sim 30 \%$ (Palmer et al., 2006), and is mainly related to uncertainties in the isoprene chemical mechanism. In tropical regions, the derivation of emissions from GOME data is made more difficult. This is to a large extent caused by the strong contribution of biomass burning to the observed HCHO signal, difficult to separate from the biogenic VOC contribution, due to its large uncertainty and spatiotemporal variability. In the global inverse modeling study of Shim et al. (2005), for example, the biomass burning source of non-methane organic compounds was increased by a factor of $2-4$ in the

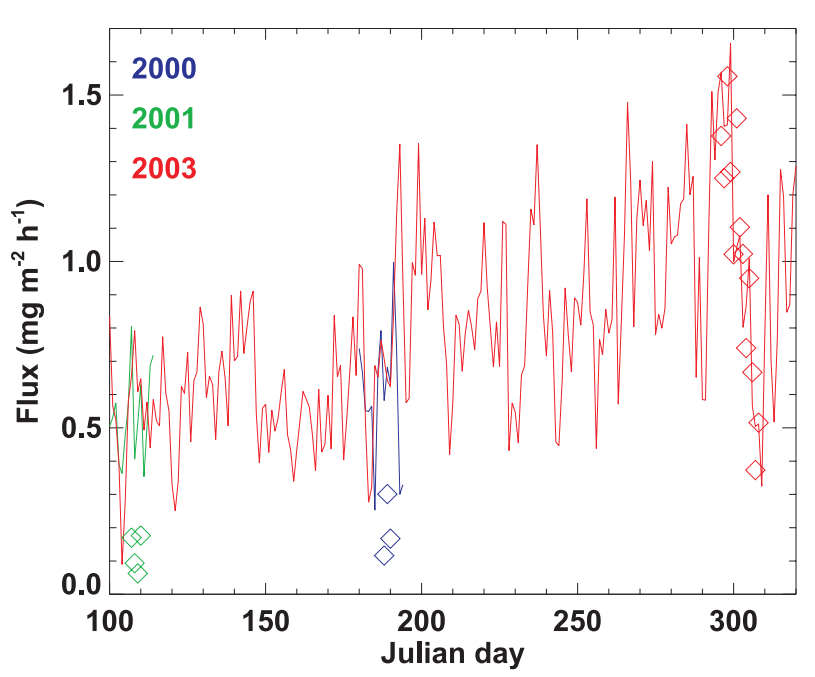

Fig. 9. Daily averaged isoprene fluxes at Tapajós (Amazonia) in 2000 (blue), 2001 (green) and 2003 (red). The diamonds are the measurements, the solid lines are the model values downscaled by a factor 1.7.

optimization, which however failed to provide a satisfactory match between the modelled and observed HCHO distributions over Africa.

We use here formaldehyde columns retrieved from GOME at IASB-BIRA (De Smedt et al., 2007). They differ from previous HCHO retrievals (e.g. Chance et al., 2000; Wittrock et al., 2000) by the choice of the wavelength interval used for DOAS (Differential Optical Absorption Spectroscopy) fitting, taken to be $328.5-346 \mathrm{~nm}$. This choice improves the slant columns and decreases the fitting residuals in tropical regions, compared with retrievals obtained with the usual fitting window $(337.5-359 \mathrm{~nm})$. Slant columns are converted to vertical columns from detailed radiative transfer calculations and vertical profile shapes of formaldehyde concentrations taken from an updated version of the IMAGES model (Müller and Stavrakou, 2005). A more detailed description of the retrieval methodology is provided in De Smedt et al. (2007, 2008 ${ }^{1}$ ).

The meteorological fields in IMAGES are obtained from ECMWF analyses for the winds, convective fluxes, temperature, and water vapour. The chemical mechanism for isoprene degradation is adapted from the MIM mechanism (Pöschl et al., 2000), with a $\mathrm{HCHO}$ yield at high $\mathrm{NO}_{\mathrm{x}}$ about $20 \%$ higher than the corresonding GEOS-Chem yield, which was found to be consistent with aircraft observations over the United States (Millet et al., 2006). The biomass burning emissions are based on the GFED v1 inventory for burnt

\footnotetext{
${ }^{1}$ De Smedt, I., Van Roozendael, M., Müller, J.-F., Stavrakou, T., Eskes, H., and Van der A., R.: Ten years of tropospheric formaldehyde retrieval from GOME and SCIAMACHY, Atmos. Chem. Phys. Discuss., submitted, 2008.
} 

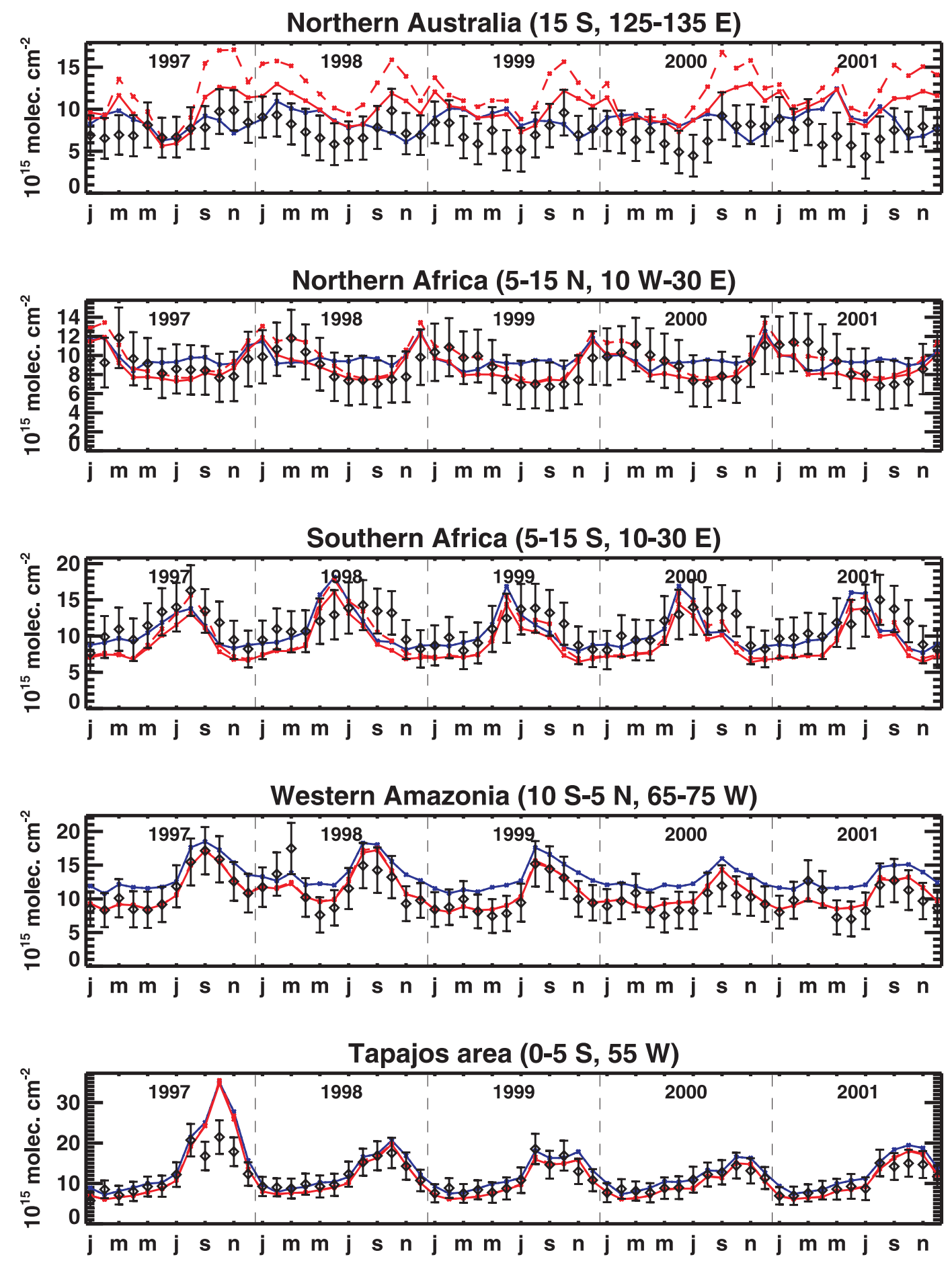

Fig. 10. Monthly averaged HCHO vertical columns in 5 regions between 1997 and 2001, retrieved from GOME data (diamonds with error bars) and calculated using the IMAGES CTM using either the GEIA 1995 inventory of Guenther et al. (1995) (blue line) or the MEGANbased inventory presented in this work (red lines). The dashed red line denotes the model results obtained using MEGAN but neglecting the soil moisture stress factor.

biomass (van der Werf et al., 2003) with emission factors of Andreae and Merlet (2001).

The modelled HCHO columns between 1997 and 2001 are compared with the GOME retrievals on Fig. 10. The blue and red lines correspond to simulations using either GEIA or MEGAN, respectively. In all regions except Southern Africa, the MEGAN-based inventory brings the seasonal variation of the modelled columns closer to the observations. 
Over Northern Australia, the MEGAN emissions appear to be overestimated, although the excellent agreement regarding the seasonal variation might indicate a systematic bias in the model and/or the data, since biogenic emissions have a strong seasonality in this region (Fig. 1). The overestimation of $\mathrm{HCHO}$ columns is worsened when the soil moisture stress activity factor is not considered in the determination of the emissions (dashed red line in Fig. 10). Over Northern Africa, the strongly reduced wet season (May-November) emissions from MEGAN compared to GEIA appear to be supported by the HCHO comparison. The wintertime discrepancies for this region are probably related to biomass burning, but the model appears to provide a better match with the data at the end of the dry season (February-April) when the soil moisture activity factor is taken equal to one. Over Southern Africa, the use of MEGAN emissions leads to a general underestimation of $\mathrm{HCHO}$ columns by the model, except at the peak of the dry season, when fires are the dominant source of reactive hydrocarbons. Over Western Amazonia, where biomass burning emissions are generally low, the lower isoprene emissions of the MEGAN-based inventory lead to a spectacular reduction of the model/data discrepancies, an improvement found at most locations in South America. At the model grid cells closest to the Tapajós forest site in the Pará province of Brazil, the model matches very well a the $\mathrm{HCHO}$ data, except in August-November 1997 when forest fires were most intense. This good agreement contradicts the analysis of the surface flux measurements discussed in Sect. 4.2, which suggested a large overestimation of isoprene fluxes at this location, in particular during the wet season. Possible explanations include the spatial variability of the emissions, and a poor representativity of the Tapajós site; the oxidation of other biogenic organic compounds not accounted for in the model; and the possible existence of large biases in the budget of oxidants, most importantly $\mathrm{OH}$, as indicated by recent findings from field campaigns in the Amazonian rainforest (Kubistin et al., 2007; Kuhn et al., 2007; Karl et al., 2007).

\section{Conclusions}

We have presented a global isoprene emission inventory covering the period 1995-2006, based on the MEGAN model. The general features of the emission distribution for the year 2003 are very consistent with the corresponding distribution calculated by Guenther et al. (2006), a logical result since the emission algorithm, but also the distributions used for LAI and the standard emission factors are adopted from this work. However, the global annual emission calculated for 2003 is about 30\% lower than in Guenther et al. (2006), to a great extent because of a stronger emission limitation due to drought calculated in our work in arid areas like Australia, subtropical Africa and the Western United States. Besides the direct impact of soil water stress on the emissions (through the $\gamma_{S M}$ activity factor of Eq. 11), drought also influences the emissions through the stomatal resistances and the leaf temperatures. We calculate that the use of leaf (instead of air) temperature in the emission algorithm increases the global annual emission by almost $20 \%$. Neglecting the soil moisture effect on the stomatal resistance calculation would not imply a large change, because the low relative humidities generally associated with drought conditions already lead to a large resistance increase.

The interannual variability of isoprene emissions is found to be higher than in a previous study (Lathière et al., 2006), with up to $20 \%$ difference between the global annual emissions of different years. This larger influence of meteorology on the emissions might be due to the ECMWF meteorological analyses adopted in our calculations and also to the dependence on past temperatures and radiation levels of the emissions in MEGAN. The highest annual global emissions are estimated for years following an El Niño event (e.g. 1998 and 2005). More precisely, the emissions are positively correlated with the Oceanic Niño Index lagged by 6 months (correlation coefficient of 0.38). The influence of El Niño is significant in both the Tropics and the higher latitudes.

Comparisons with tower flux measurements at a midlatitude forest site and in the Amazonian rain forest show the ability of the model to reproduce the short-term variations in isoprene emissions. Long-term variations are not so well reproduced, as illustrated by the strong overestimation of the modelled fluxes during the wet season (in April and July) at Tapajós. The average model/data biases at Harvard forest during the summer (underestimation by factor 1.35) and at Tapajós in the dry season (overestimation by factor 1.7) might be indications that the standard emission rates used in MEGAN are inappropriate at these locations; however, the representativity of these sites for larger-scale flux estimations might be limited (e.g. Karl et al., 2007). Further measurements are obviously needed to better ascertain the spatiotemporal variability of the emissions, especially over tropical rainforests. Satellite measurements of formaldehyde, a major isoprene degradation by-product, might prove to be very useful for constraining the emissions and their variability, as illustrated by comparisons of GOME vertical columns with global models over the United States (Palmer et al., 2006), over Southeast Asia (Fu et al., 2007), or over other regions like Africa, South America and Australia (Fig. 10). Further work will be essential in order to improve the CTMs, e.g. regarding the chemical mechanism in low- $\mathrm{NO}_{\mathrm{x}}$ conditions, the emissions and chemistry of other biogenic NMVOCs, and the emissions and chemistry of compounds released by vegetation fires, which also contribute to the total HCHO signal observed from the satellites. Synergies should be also developed for a better integration of surface (or aircraft) campaign measurements in conjunction with analyses using satellite data.

Acknowledgements. This work was partly supported by a contract in the framework of the Belgian Research programme on Global 
Change and Sustainable Development, and by PRODEX programme of ESA, both funded by the Belgian Science Policy Office.

Edited by: A. Hofzumahaus

\section{References}

Abbott, D. S., Palmer, P. I., Martin, R. V., Chance, K. V., Jacob, D. J., and Guenther, A.: Seasonal and interannual variability of North American isoprene emissions as determined by formaldehyde column measurements from space, Geophys. Res. Lett., 30, 1886, doi:10.1029/2003GL017336, 2003.

Andreae, M. O. and Merlet, P.: Emission of trace gases and aerosols from biomass burning, Global Biogeochem. Cycles, 15, 955966, 2001.

Chance, K., Palmer, P. I., Spurr, R. J. D., Martin, R. V., Kurosu, T. P., and Jacob, D. J.: Satellite observations of formaldehyde over North America from GOME, Geophys. Res. Lett., 27, 3461-3464, 2000.

Chen, F. and Dudhia, J.: Coupling an Advanced Land Surface Hydrology Model with the Penn State - NCAR MM5 Modeling System. Part I: Model Implementation and Sensitivity, Mon. Weather Rev., 129(4), 569-585, 2001.

Dentener, F., Stevenson, D., Ellingsen, K., et al.: The global atmospheric environment for the next generation, Environ. Sci. Technol., 40, 3586-3594, 2006.

De Smedt, I., Van Roozendael, M., Stavrakou, T., Müller, J.-F., Van der A, R., and Eskes, H.: Global observations of formaldehyde in the troposphere by satellites; GOME and SCIAMACHY results, Proc. ENVISAT Conference 2007, Montreux, 2007.

Fu, T.-M., Jacob, D. J., Palmer, P. I., Chance, K., Wang, Y. X., Barletta, B., Blake, D. R., Stanton, J. C., and Pilling, M. J.: Space-based formaldehyde measurements as constraints on volatile organic compound emissions in east and south Asia and implications for ozone, J. Geophys. Res., 112, D06312, doi:10.29/2006JG007853, 2007.

Goldstein, A., Goulden, M., Munge, W., Wofsy, S., and Geron, C.: Seasonal course of isoprene emissions from a midlatitude deciduous forest, J. Geophys. Res., 103, 31 045-31 056, 1998.

Goudriaan, J. and van Laar, H.: Modelling Potential Crop Growth Processes. Textbook with Exercises. Kluwer Academic Publishers, Dordrecht, The Netherlands, 1994.

Guenther, A., Hewitt, C. N., Erickson, D., Fall, R., Geron, C., Graedel, T., Harley, P., Klinger, L., Lerdau, M., McKay, W. A., Pierce, T., Scholes, B., Steinbrecher, R., Tallamraju, R., Taylor, J. and Zimmerman, P.: A global model of natural volatile organic compound emissions, J. Geophys. Res., 100, 8873-8892, 1995.

Guenther, A. and Hills, A.: Eddy covariance measurement of isoprene fluxes, J. Geophys. Res., 103(D11), 13 145-13 152, 1998.

Guenther, A., Karl T., Harley P., Wiedinmyer, C., Palmer P., and Geron, C.: Estimates of global terrestrial isoprene emissions using MEGAN (Model of Emissions of Gases and Aerosols from Nature), Atmos. Chem. Phys., 6, 3181-3210, 2006,

http://www.atmos-chem-phys.net/6/3181/2006/.

Huete, A., Didan, K., Shimabukuro, Y., Ratana, P., Saleska, S., Hutyra, L., Nemani, R., and Myneni, R.: Amazon rainforests green-up with sunlight in dry season, Geophys. Res. Lett., 33, L06405, doi:10.1029/2005GL025583, 2006.
Kalnay, E., Kanamitsu, M., Kistler, R., et al.: The NCEP/NCAR 40-year reanalysis project, B. Am. Meteorol. Soc., 77, 437-470, 1996.

Karl, T. G., Guenther, A., Yokelson, R. J., Greenberg, J., Potosnak, M. J., Blake, D. R., and Artaxo, P.: The tropical forest and fire emissions experiment: Emission, chemistry, and transport of biogenic volatile organic compounds in the lower atmosphere over Amazonia, J. Geophys. Res., 112, D18302, doi:10.1029/2007JD008539, 2007.

Kubistin, D., Harder, H., Martinez, M., et al.: Hydroxyl radicals in the Tropical troposphere during GABRIEL: Comparison of measurements with the box model MECCA (2007), Geophys. Res. Abs., 9, 07065, 2007.

Kuhn, U., Rottenberger, S., Biesenthal, T., Wolf, A., Schebeske, G., Ciccioli, P., Brancaleoni, E., Frattoni, M., Tavares, T. M., and Kesselmeier, J.: Seasonal differences in isoprene and lightdependent monoterpene emission by Amazonian tree species, Global Change Biol., 10, 663-682, 2004.

Kuhn, U., Andreae, M. O., Ammann, C., et al.: Isoprene and monoterpene fluxes from Central Amazonian rainforest inferred from tower-based and airborne measurements, and implications on the atmospheric chemistry and the local carbon budget, Atmos. Chem. Phys., 7, 2855-2879, 2007,

http://www.atmos-chem-phys.net/7/2855/2007/.

Lathière, J., Hauglustaine, D.A., Friend, A., De Noblet-Ducoudr, N., Viovy, N., and Folberth, G.: Impact of climate variability and land use changes on global biogenic volatile organic compound emissions, Atmos. Chem. Phys., 6, 2129-2146, 2006,

http://www.atmos-chem-phys.net/6/2129/2006/.

Leuning, R., Kelliher, F., De Purry, D., and Schulze, E.-D.: Leaf nitrogen, photosynthesis, conductance and transpiration: scaling from leaves to canopies, Plant Cell Environ., 1195, 18, 11831200, 1995.

Li, H. and Robock, A.: Evaluation of reanalysis soil moisture simulations using updated Chinese soil moisture observations, J. Hydrometeorol., 6, 180-193, 2005.

Madronich, S. and Flocke, S.: The role of solar radiation in atmospheric chemistry, in: Handbook of Environmental Chemistry, edited by: Boule, P., Springer Verlag, Heidelberg, 1-26, 1998.

Maurer, E. P., Wood, A. W., Adam, J. C., and Lettenmaier, D. P.: A long-term hydrologically based dataset of land surface fluxes and states for the conterminous United States, J. Climate, 15, 32373251, 2002.

Müller, J.-F.: Geographical distribution and seasonal variation of surface emissions and deposition velocities of atmospheric trace gases, J. Geophys. Res., 97, 3787-3804, 1992.

Müller, J.-F. and Stavrakou, T.: Inversion of CO and NOx emissions using the adjoint of the IMAGES model, Atmos. Chem. Phys., 5, 1157-1186, 2005, http://www.atmos-chem-phys.net/5/1157/2005/.

Naik, V., Delire, C., and Wuebbles, D. J.: Sensitivity of global biogenic isoprenoid emissions to climate variability and atmospheric CO2, J. Geophys. Res., 109(D6), D06301, doi:10.1029/2003JD004236, 2004.

Millet, D. B., Jacob, D. J., Turquety, S., Hudman, R. C., Wu, S., Fried, A., Walega, J., Heikes, B. G., Blake, D. R., Singh, H. B., Anderson, B. E., and Clarke, A. D.: Formaldehyde distribution over North America: Implications for satellite retrievals of formaldehyde columns and isoprene emission, J. Geophys. Res., 
111, D24S02, doi:10.1029/2005JD006853, 2006.

Olson, J. S., Watts, J. A., and Allison, L. J.: Major world ecosystem complexes ranked by carbon in live vegetation, A data base, ORNL-5862, 164 pp., Oak Ridge National Laboratory, Oak Ridge, Tenn., 1985.

Palmer, P. I., Jacob, D. J., Fiore, A. M., Martin, R. MV., Chance, K., and Kurosu, T. P.: Mapping isoprene emissions over North America using formaldehyde column observations from space, J. Geophys. Res., 108(D6), 4180, doi:10.129/2002JD002153, 2003.

Palmer, P. I., Abbott, D. S., Fu, T.-M., Jacob, D. J., Chance, K., Kurosu, T. P., Guenther, A., Wiedinmyer, C., Stanton, J. C., Pilling, M. J., Pressley, S. N., Lamb, B., and Sumner, A. L.: Quantifying the seasonal and interannual variability of North American isoprene emissions using satellite observations of the formaldehyde column, J. Geophys. Res., 111, D12315, doi:1029/2005JD006689, 2006.

Pegoraro, E., Rey, A., Murthey, R., Bobich, E., Barron-Gafford, G., Grieve, K., and Malhi, Y.: Effect of $\mathrm{CO} 2$ concentration and vapour pressure deficit on isoprene emission from leaves of Populus deltoides during drought, Functional Plant Biology, 31(12), 456-463, 2004.

Pfister, G., Emmons, L. K., Hess, P. G., Lamarque, J.-F., Walters, S., Guenther, A. , Palmer, P. I., Lawrence, P. J.: Contribution of isoprene to chemical budgets: A model tracer study with the NCAR CTM MOZART-4, J. Geophys. Res., in press, 2008.

Pöschl, U., von Kuhlmann, R., Poisson, N., and Crutzen, P. J.: Development and intercomparison of condensed isoprene oxidation mechanisms for global atmospheric modeling, J. Atmos. Chem., 37, 29-52, 2000.

Rinne, J., Guenther, A., Greenberg, J., and Harley, P.: Isoprene and monoterpene fluxes measured above Amazonian rainforest and their dependence on light and temperature, Atmos. Environ., 36, 2421-2426, 2002.

Rossow, W. and Schiffer, R.: ISCCP Cloud Data Products, B. Am. Meteorol. Soc., 72(1), 2-20, 1991.

Rossow, W. B., Walker, A. W., Beuschel, D. E., and Roiter, M. D.: International Satellite Cloud Climatology Project (ISCCP) Documentation of New Cloud Datasets: Report WMO/TD-No. 737, World Meteorological Organization, Geneva, 1996.

Sanderson, M. G., Jones, C. D., Collins, W. J., Johnson, C. E., and Derwent, R. G.: Effect of climate change on isoprene emissions and surface ozone levels, Geophys. Res. Lett., 30, 18, doi:10.1029/2003GL017642, 2003.
Seinfeld, J. and Pandis, S. N.: Atmos. Chem. Phys., John Wiley and Sons, New York, 1998.

Sellers, P.: Canopy reflectance, photosynthesis and transpiration, J. Atmos. Sci., 43(6), 505-531, 1985.

Sellers, P., Mintz, Y., Sud, Y., and Dalcher, A.: A Simple Biosphere Model (SiB) for Use within General Circulation Models, J. Atmos. Sci., 43(6), 505-531, 1986.

Shim, C., Wang, Y., Choi, Y., Palmer, P. I., Abbot, D. S., and Chance, K.: Constraining global isoprene emissions with Global Ozone Monitoring Experiment (GOME) formaldehyde column measurements, J. Geophys. Res., 110, D24301, doi:1029/2004JD005629, 2005.

Simon, E., Kuhn, U., Rottenberger, S., Meixner, F. X., and Kesselmeier, J.: Coupling isoprene and monoterpene emissions from Amazonian tree species with physiological and environmental parameters using a neural network approach, Plant Cell Environ., 28, 287-301, 2005.

Trostdorf, C., Gatti, L., Yamazaki, A., Potosnak, M., Guenther, A., Martins, W., and Munger, J.: Seasonal cycles of isoprene concentrations in the Amazonian rainforest, Atmos. Chem. Phys. Discuss., 4, 1291-1310, 2004,

http://www.atmos-chem-phys-discuss.net/4/1291/2004/.

van der Werf, G., Randerson, J. T., Collatz, G. J., and Giglio, L.: Carbon emissions from fires in tropical and subtropical ecosystems, Global Change Biol., 9, 547-562, 2003.

Wallens, S.: Modélisation des émissions de composés organiques volatils par la végétation, $\mathrm{PhD}$ Thesis, Université Libre de Bruxelles, Brussels, 2004.

Wittrock, F., Richter, A., Ladstätter-Weissenmayer, A., and Burrows, J. P.: Global observations of formaldehyde, Proc. ERSENVISAT Symposium, ESA-Publ. SP-461, 2000.

Zeng, X.: Global Vegetation Root Distribution for Land Modeling, J. Hydrometeorol., 2(5), 525-530, 2001.

Zhang, P., Anderson, B., Barlow, M., Tan, B., and Myneni, R.: Climate related vegetation charasteristics derived from MODIS LAI and NDVI, J. Geophys. Res., 109, D20105, doi:10129/2004JD004720, 2004. 